\title{
ALFABETIZAÇÃO: UMA REFLEXÃO SOBRE AS CONCEPÇÕES PARA O ENSINO DE LEITURA E ESCRITA, UM DIREITO A SER ADQUIRIDO MEDIANTE O ENTENDIMENTO GLOBAL
}

\author{
Joara Aparecida Ribeiro Schran Gil ${ }^{1}$ \\ Mariana Aranha de Souza²
}

Resumo: Este artigo evidencia a importância da alfabetização para o ensino da leitura e da escrita, uma análise qualitativa que descreve a percepção das professoras entrevistadas. Pretende-se trazer a discussão, a complexa atividade de alfabetizar, a partir da reflexão sobre as ações, as estratégias e as atitudes do professor alfabetizador na busca por um ensino de qualidade que se efetive na fase inicial da escolarização, hoje ampliada para os três primeiros anos da Educação Básica. O exame minucioso das concepções a respeito do ensino da leitura e escrita, bem como a análise das teorias de alfabetização e letramento no tocante a importância do papel do professor para o ensino são os objetivos deste estudo, como ferramenta primordial para o entendimento e a comunicação em um mundo globalizado.

Palavras-chave: Alfabetização; Leitura e Escrita; Concepções; Reflexão.

\footnotetext{
1 Mestre em Educação pelo Programa de Pós-Graduação em Educação e Desenvolvimento Humano, pela Universidade de Taubaté/UNITAU, Brasil. E-mail: aparecidajosgil@hotmail.com.

2 Mestre e Professora Doutora Colaboradora do Programa de Mestrado em Desenvolvimento Humano: Formação, Políticas e Práticas Sociais do Programa de Mestrado em Educação e Assessora Pedagógica da Educação à Distância da Universidade de Taubaté/UNITAU, Brasil. E-mail: profa.maaranha@gmail.com.
} 